\title{
Avian collisions with power lines: a global review of causes and mitigation with a South African perspective
}

\author{
ANDREW R. JENKINS, JON J. SMALLIE and MEGAN DIAMOND
}

\begin{abstract}
Summary
Many large terrestrial and wetland birds and some smaller, fast-flying species are prone to colliding with overhead wires associated with power infrastructure. A high proportion of these are threatened species and for some, collision with power lines and other man-made structures is a significant and damaging source of anthropogenic mortality. We review the existing literature on the nature, scale and impact of this problem worldwide, with particular emphasis on the South African situation, and focus on the evidence for and against various line configurations and devices proposed to mitigate the negative effects of overhead lines on bird populations. Cranes, bustards, flamingos, waterfowl, shorebirds, gamebirds and falcons are among the most frequently affected avian groups, and collision frequency is thought to be an influential factor in ongoing population declines in several species of cranes, bustards and diurnal raptors. The bulk of the research on this issue has been done in North America, Scandinavia, southern Europe and South Africa. Few comprehensive experimental studies on ways to reduce avian collisions with power lines have been carried out, although most of these have yielded quite clear results. Mitigation options considered include reviewing the placement of proposed new lines, removing the earth-wire which is usually the highest, thinnest and most problematic component in an overhead power line configuration, or else fitting this wire with markers - brightly coloured 'aviation' balls, thickened wire coils, luminescent, shiny or hinged flashing or flapping devices. All of these options reduce bird collision frequency overall by at least $50-60 \%$, although the efficacy of line marking may be much lower for certain species (e.g. bustards). There remains considerable uncertainty about the best-performing marking device (perhaps because performance may vary with both local conditions and the species involved in each instance), and a durable, all-purpose device, that is effective both during the day and at night, has not yet been developed. We conclude by outlining a proposed experimental evaluation of the full array of collision mitigation options, to select the best approaches for use under South African conditions.
\end{abstract}

\section{Introduction}

Over 65 million $\mathrm{km}$ of medium-high voltage power lines are presently in use around the world (ABS Energy Research 2008). This network is growing at a rate of about $5 \%$ annually, and the total value of the global electricity transmission and distribution industry exceeded US\$200 billion in 2006/ 2007. Numerous published and unpublished studies have clearly demonstrated that overhead high tension wires or cabling, and particularly commercial power lines, pose a collision risk to flying birds, and these have been regionally, nationally and internationally summarised in a number of valuable review papers (e.g. APLIC 1994, Bevanger 1994, 1998, Janss 2000, IEEE Task Force 2004, Erickson et al. 2005, Rubolini et al. 2005, Drewitt and Langston 2008). While there is some generic knowledge of why and where avian collision mortality is most likely to occur (Bevanger 1994, 1998, Janss 2000), and of the kinds of taxa most significantly affected (Rubolini et al. 2005), 
understanding of the scale and demographic consequences of power line collisions is generally poor, and progress in the development of effective means to mitigate collision risk has been limited.

South Africa's core energy grid comprises over 350,000 km of power lines (www.eskom.co.za), and will increase significantly in extent with a capacity expansion budget currently in excess of $\mathrm{R}_{3} \mathrm{OO}$ billion (US\$ 25 billion). In 1995, South Africa's only power utility, Eskom, formalised a strategic partnership with the Endangered Wildlife Trust (EWT), a non-governmental conservation organisation, with the express goal of researching, managing and minimising harmful environmental impacts of the power generation and delivery process (van Rooyen and Ledger 1999, van Rooyen 2000, 2001). The partnership has acknowledged the occurrence and possible significance of power line collisions, and reactively implemented various stop-gap measures and devices to combat this problem (van Rooyen 2001). However, in keeping with worldwide trends, these efforts have not yet yielded a proven and reliably effective collision mitigation strategy (Jenkins et al. 2008).

The present study provides an overview of the state of the art in avian collision biology and collision mitigation, both globally and locally in South Africa, including a comprehensive list of suggested remedial options, and synthesises the major published or peer-reviewed work on bird:power line collision mitigation. The primary aims are (i) to draw whatever firm conclusions are possible about collision mitigation from the available scientific evidence, and the results of rigorous experimental work done to date, (ii) to identify the obvious gaps in our knowledge, both globally and locally, which presently obstruct progress towards a successful remedial plan for bird:power line collisions, and (iii) to propose a programme for future progressive work in this field in South Africa.

\section{Methods}

As far possible, and to obtain maximum practical benefit from the process, the literature review was done systematically and in terms of a proposed set of guidelines (Pullin and Stewart 2006, Lehman et al. 2007). These were focused on addressing pre-determined aims (listed above), by means of an objective and structured evaluation of the available information. The published scientific literature was searched (using the internet database ISIS Web of knowledge, including Web of Knowledge, BIOSIS and Zoological Record) for recent (post-1980) papers which either review causal aspects of avian:power line collisions, or detail original casualty rates at particular collision hot-spots, possibly in combination with a quantitative evaluation of at least one collision mitigation strategy. These studies were supplemented by information available only in the form of 'grey' reports, mostly those commissioned by power utilities (including Eskom in South Africa) and available either online (and located using the internet search engine Google ${ }^{\mathrm{TM}}$ ) or on request from the author, but not published in the open literature. Finally, the California Energy Commission's 'Annotated online bibliography of avian interactions with utility structures' was also searched for any outstanding publications or reports (www.energy.ca.gov/research/environmental/avian_bibliography)

Salient details (including geographic scope, affected taxa, contributing factors and suggested mitigation) were extracted from review papers and documents, tabulated for each, and are presented in a brief, integrated, descriptive synthesis. Original studies detailing collision frequencies were dealt with in a similar way. Original studies in which collision mitigation measures were tested are reviewed in more detail, and the particulars of the mitigation practice examined, the experimental procedures and analyses used, and the value and implications of the results, were extracted and tabulated in a comparable way. South African studies and data are highlighted and contextualised in this review process.

\section{Results and Discussion}

Eight review papers, 13 papers or reports detailing original data on the incidence of collisions, and 12 papers or reports on the efficacy of a variety of mitigation options formed the basis of this study (Appendices 1 and 2 in Supplementary Materials; Table 1). The bulk of the meaningful 
Table 1 . Field studies incorporating quantitative evaluation of at least one avian collision mitigation strategy or device.

\begin{tabular}{|c|c|c|c|c|c|c|}
\hline $\begin{array}{l}\text { Reference/ Geographic area/ } \\
\text { Affected taxa/ }\end{array}$ & Voltage of line/s & $\begin{array}{l}\text { Duration of } \\
\text { study / } \\
\text { length/s of } \\
\text { line }\end{array}$ & Size or variant of mitigating device & Experimental design & $\begin{array}{l}\text { Measured or } \\
\text { estimated effect } \\
\text { of mitigation on } \\
\text { behaviour? }\end{array}$ & $\begin{array}{l}\text { Measured or } \\
\text { estimated effect of } \\
\text { mitigation on } \\
\text { casualty rate? }\end{array}$ \\
\hline \multicolumn{7}{|l|}{ Removal of earth wire } \\
\hline $\begin{array}{l}\text { Brown et al. } \\
\text { 1987/Colorado, } \\
\text { U.S.A./Sandhill } \\
\text { Crane Grus } \\
\text { canadensis and } \\
\text { Whooping Cranes } \\
\text { G. americana }\end{array}$ & $115 \mathrm{kV}$ & $\begin{array}{l}2 \text { years / } \\
3.2 \mathrm{~km}\end{array}$ & - & $\begin{array}{l}\text { Section monitored for } 5 \\
\text { months, then earth wire } \\
\text { removed for } 12 \text { months, } \\
\text { then } 1 / 2 \text { replaced with } \\
\text { normal earth-wire and } 1 / 2 \\
\text { with wire } 3 \times \text { thicker }\end{array}$ & - & $\begin{array}{l}>80 \% \text { reduction } \\
\text { in crane collision } \\
\text { rate with removal } \\
\text { of earth wire. } \\
\text { Return to similar } \\
\text { casualty rate with } \\
\text { replacement of } \\
\text { earth wire, even } \\
\text { with thicker wire } \\
\text { on } 1 / 2 \text { of length }\end{array}$ \\
\hline $\begin{array}{l}\text { Bevanger and } \\
\text { Brøseth 2001/ } \\
\text { Norway/ } \\
\text { Ptarmigan spp. }\end{array}$ & $\begin{array}{l}22,66 \text { and } \\
300 \mathrm{kV}\end{array}$ & $\begin{array}{l}6 \text { years / } \\
10 \mathrm{~km}\end{array}$ & - & $\begin{array}{l}3 \text { sections of line }-5 \mathrm{~km} \text { of } \\
300 \mathrm{kV} \text { with raised earth- } \\
\text { wire, } 2.5 \mathrm{~km} \text { of } 66 \mathrm{kV} \text { with } \\
\text { no earth-wire, and } 2.5 \mathrm{~km} \\
\text { of } 22 \mathrm{kV} \text { with lower earth- } \\
\text { wire. In } 4^{\text {th }} \text { year of study, } \\
\text { earth-wire removed from } \\
22 \mathrm{kV} \text { line }\end{array}$ & - & $\begin{array}{l}\text { No difference in } \\
\text { collision rate on } \\
\text { control lines, } \\
\text { experimental line } \\
\text { casualties dropped } \\
\text { by }>50 \%\end{array}$ \\
\hline \multicolumn{7}{|c|}{ Bands or stripes on conductors } \\
\hline $\begin{array}{l}\text { Janss and Ferrer } \\
\text { 1998/ } \\
\text { Extremadura, Spain/26 } \\
\text { spp. (incl. cranes and } \\
\text { bustards) }\end{array}$ & $132 \mathrm{kV}$ & $\begin{array}{c}>4 \text { years / } \\
3.9 \mathrm{~km}\end{array}$ & $\begin{array}{l}2 \text { black, neoprene bands ( } 35 \times \\
5 \mathrm{~cm} \text { ), crossed, with a bright } \\
\text { stripe, fixed every } 20 \mathrm{~m} \text { with } \\
\text { plastic peg }\end{array}$ & $\begin{array}{l}\text { Line without markers for } 2 \\
\text { years, surveyed every } 1-2 \\
\text { months. Markers placed } \\
\text { on every other span for } \\
\text { second study period, and } \\
\text { surveyed monthly }\end{array}$ & - & $\begin{array}{l}76 \% \text { reduction in } \\
\text { overall casualty } \\
\text { rate, but no effect } \\
\text { on Great Bustard } \\
\text { collisions }\end{array}$ \\
\hline
\end{tabular}


Table 1. Continued.

\begin{tabular}{|c|c|c|c|c|c|c|}
\hline $\begin{array}{l}\text { Reference/ Geographic area/ } \\
\text { Affected taxa/ }\end{array}$ & Voltage of line/s & $\begin{array}{l}\text { Duration of } \\
\text { study / } \\
\text { length/s of } \\
\text { line }\end{array}$ & Size or variant of mitigating device & Experimental design & $\begin{array}{l}\text { Measured or } \\
\text { estimated effect } \\
\text { of mitigation on } \\
\text { behaviour? }\end{array}$ & $\begin{array}{l}\text { Measured or } \\
\text { estimated effect of } \\
\text { mitigation on } \\
\text { casualty rate? }\end{array}$ \\
\hline $\begin{array}{l}\text { Janss and Ferrer } \\
\text { 1998/ } \\
\text { Extremadura, } \\
\text { Spain/26 spp. } \\
\text { (incl. cranes and } \\
\text { bustards) }\end{array}$ & $132 \mathrm{kV}$ & $\begin{array}{c}>4 \text { years / } \\
1.2 \mathrm{~km}\end{array}$ & $\begin{array}{l}3 \text { thin plastic stripes, } 70 \mathrm{~cm} \times 0.8 \\
\mathrm{~cm} \text {, hanging every } 12 \mathrm{~m} \text { from } \\
\text { centre conductor }\end{array}$ & $\begin{array}{l}\text { Line without markers for } 2 \\
\text { years, surveyed every 1-2 } \\
\text { months. Markers placed } \\
\text { on every other span for } \\
\text { second study period, and } \\
\text { surveyed monthly }\end{array}$ & - & $\begin{array}{l}\text { No significant } \\
\text { reduction in } \\
\text { collision rate }\end{array}$ \\
\hline \multicolumn{7}{|l|}{ Coloured aviation balls } \\
\hline $\begin{array}{l}\text { Morkill and } \\
\text { Anderson 1991/ } \\
\text { Nebraska, U.S.A./ } \\
\text { Sandhill Crane }\end{array}$ & $69-345 \mathrm{kV}$ & $\begin{array}{l}3 \text { years / } 9 \\
\text { lines of } 1.0 \\
\text { to } 2.5 \mathrm{~km}, \\
\text { totalling } 14 \\
\mathrm{~km}\end{array}$ & $\begin{array}{l}30 \mathrm{~cm} \text { diameter, yellow aviation } \\
\text { balls with black stripes, placed on } \\
\text { earth wire on alternating spans, } \\
\text { with balls at } 100 \mathrm{~m} \text { intervals on } \\
\text { opposing wires, so effectively } \\
\text { every } 50 \mathrm{~m}\end{array}$ & $\begin{array}{l}\text { Daily watches of crane } \\
\text { movements, and daily } \\
\text { searches for collision } \\
\text { casualties, throughout } \\
\text { spring migration in each } \\
\text { year }\end{array}$ & $\begin{array}{l}\text { Cranes more } \\
\text { likely to } \\
\text { gradually lift } \\
\text { over marked } \\
\text { than unmarked } \\
\text { spans, from } \\
\text { further away, } \\
\text { as opposed to } \\
\text { suddenly } \\
\text { changing flight } \\
\text { attitude when } \\
\text { close to the line }\end{array}$ & $\begin{array}{l}\text { Casualty rate } \\
54 \% \text { lower under } \\
\text { marked lines }\end{array}$ \\
\hline $\begin{array}{l}\text { Savereno et al. } \\
\text { 1996/South } \\
\text { Carolina, U.S.A./ } \\
\text { Various }\end{array}$ & $115 \mathrm{kV}$ & $\begin{array}{l}3 \text { years / } 2 \\
\text { lines of } 3.9 \\
\text { (marked) } \\
\text { and } 1.2 \mathrm{~km} \\
\text { (unmarked) }\end{array}$ & $\begin{array}{l}30 \mathrm{~cm} \text { diameter, yellow aviation } \\
\text { balls with black stripes, placed on } \\
\text { earth wire on experimental line, } \\
\text { with balls at } 61 \mathrm{~m} \text { intervals on } \\
\text { opposing wires, so effectively } \\
\text { every } 50 \mathrm{~m}\end{array}$ & $\begin{array}{l}\text { Direct comparison of bird } \\
\text { behaviour and mortality } \\
\text { rates at similar marked vs } \\
\text { unmarked lines }\end{array}$ & $\begin{array}{l}\text { Approaching } \\
\text { birds changed } \\
\text { course more on } \\
\text { marked than on } \\
\text { unmarked line, } \\
\text { and fewer } \\
\text { crossed } \\
\text { between the } \\
\text { earth wire and } \\
\text { the conductors }\end{array}$ & $\begin{array}{l}\text { Collision rate } \\
53 \% \text { lower at } \\
\text { marked line }\end{array}$ \\
\hline
\end{tabular}




\begin{tabular}{|c|c|c|c|c|c|c|}
\hline $\begin{array}{l}\text { Reference/ Geographic area/ } \\
\text { Affected taxa/ }\end{array}$ & Voltage of line/s & $\begin{array}{l}\text { Duration of } \\
\text { study / } \\
\text { length/s of } \\
\text { line }\end{array}$ & Size or variant of mitigating device & Experimental design & $\begin{array}{l}\text { Measured or } \\
\text { estimated effect } \\
\text { of mitigation on } \\
\text { behaviour? }\end{array}$ & $\begin{array}{l}\text { Measured or } \\
\text { estimated effect of } \\
\text { mitigation on } \\
\text { casualty rate? }\end{array}$ \\
\hline \multicolumn{7}{|c|}{ Static vibration damper, spirals, BFDs or 'pig-tails' } \\
\hline $\begin{array}{l}\text { Alonso et al. } \\
\text { 1994/ Extremadura, } \\
\text { Spain/30 spp. } \\
\text { (incl. cranes and } \\
\text { bustards) }\end{array}$ & $380 \mathrm{kV}$ & $\begin{array}{l}2 \text { years / } 4 \\
\text { sections of } \\
4.2-8.8 \mathrm{~km} \text {, } \\
\text { total } 28.2 \\
\mathrm{~km}\end{array}$ & $\begin{array}{l}\text { Red PVC spirals, I m long } \times 30 \mathrm{~cm} \\
\text { diameter, attached to both earth- } \\
\text { wires at } 10 \mathrm{~m} \text { intervals }\end{array}$ & $\begin{array}{l}\text { One season of collision and } \\
\text { activity surveys, sections } \\
\text { of each survey section } \\
\text { marked with spirals (total } \\
12.5 \mathrm{~km} \text { marked), one } \\
\text { season of post-marking } \\
\text { data collection }\end{array}$ & $\begin{array}{l}61 \% \text { reduction in } \\
\text { numbers of } \\
\text { birds crossing } \\
\text { the line } \\
\text { corridor post- } \\
\text { marking. More } \\
\text { birds flying } \\
\text { over cables, } \\
\text { fewer flying } \\
\text { through }\end{array}$ & $\begin{array}{l}60 \% \text { reduction in } \\
\text { collision frequency } \\
\text { post-marking }\end{array}$ \\
\hline $\begin{array}{l}\text { Brown and } \\
\text { Drewien 1995/ } \\
\text { Colorado, U.S.A./ } \\
\text { Cranes and } \\
\text { waterfowl }\end{array}$ & $\begin{array}{l}7.2 \text { and } \\
69-115 \mathrm{kV}\end{array}$ & $\begin{array}{l}3 \text { years / } 8 \\
\text { sections of } \\
1.2-2.4 \mathrm{~km} \text {, } \\
\text { total } \\
13.2 \mathrm{~km}\end{array}$ & $\begin{array}{l}\text { Bright yellow PVC vibration } \\
\text { dampers, } 112-125 \mathrm{~cm} \text { long } \times 1.3 \mathrm{~cm} \\
\text { diameter, attached to uppermost or } \\
\text { all earth-wires at } 3.3 \mathrm{~m} \text { intervals }\end{array}$ & $\begin{array}{l}\text { Half of each section marked, } \\
1 / 2 \text { left unmarked, all } \\
\text { checked daily, throughout } \\
3 \text { falls and } 3 \text { springs - bird } \\
\text { activity and response and } \\
\text { collision rates compared }\end{array}$ & $\begin{array}{l}\text { Birds reacted } \\
\text { earlier and flew } \\
\text { higher over } \\
\text { marked lines } \\
\text { than unmarked } \\
\text { lines }\end{array}$ & $\begin{array}{l}61 \% \text { reduction in } \\
\text { mortality rates } \\
\text { overall, but } \\
\text { considerable } \\
\text { seasonal variation. } \\
\text { Over } 30 \% \text { of } \\
\text { collisions in fall } \\
\text { occurred at night }\end{array}$ \\
\hline $\begin{array}{l}\text { Janss and Ferrer } \\
\text { 1998/ } \\
\text { Extremadura, } \\
\text { Spain/ } 26 \text { spp. } \\
\text { (incl. cranes and } \\
\text { bustards) }\end{array}$ & $380 \mathrm{kV}$ & $\begin{array}{c}>4 \text { years / } \\
4.5 \mathrm{~km}\end{array}$ & $\begin{array}{l}\text { White polypropylene spirals, } 1 \mathrm{~m} \\
\text { long, } 30 \mathrm{~cm} \text { diameter, staggered } \\
\text { on two static wires to effect } \\
\text { marking every } 5 \mathrm{~m}\end{array}$ & $\begin{array}{l}\text { Line without markers for } 2 \\
\text { years, surveyed every 1-2 } \\
\text { months. Markers placed } \\
\text { on every other span for } \\
\text { second study period, and } \\
\text { surveyed monthly }\end{array}$ & - & $\begin{array}{l}81 \% \text { reduction in } \\
\text { overall casualty } \\
\text { rate, Common } \\
\text { Crane collisions } \\
\text { reduced but not } \\
\text { significantly }\end{array}$ \\
\hline
\end{tabular}


Table 1. Continued.

\begin{tabular}{|c|c|c|c|c|c|c|}
\hline $\begin{array}{l}\text { Reference/ Geographic area/ } \\
\text { Affected taxa/ }\end{array}$ & Voltage of line/s & $\begin{array}{l}\text { Duration of } \\
\text { study / } \\
\text { length/s of } \\
\text { line }\end{array}$ & Size or variant of mitigating device & Experimental design & $\begin{array}{l}\text { Measured or } \\
\text { estimated effect } \\
\text { of mitigation on } \\
\text { behaviour? }\end{array}$ & $\begin{array}{l}\text { Measured or } \\
\text { estimated effect of } \\
\text { mitigation on } \\
\text { casualty rate? }\end{array}$ \\
\hline $\begin{array}{l}\text { Anderson 2002/ } \\
\text { Karoo, South } \\
\text { Africa/Various, } \\
\text { but mainly } \\
\text { Ludwig's Bustard } \\
\text { and Blue Crane }\end{array}$ & $132 \mathrm{kV}$ & $\begin{array}{l}3 \text { years / } \\
10 \mathrm{~km}\end{array}$ & $\begin{array}{l}\text { PVC Bird Flight Diverter, } 30 \mathrm{~cm} \\
\text { long, attached to both earth wires } \\
\text { every } 10 \mathrm{~m}\end{array}$ & $\begin{array}{l}\text { Surveyed collisions for } \\
\text { a year before and for } 2 \\
\text { years after marking }\end{array}$ & - & $\begin{array}{l}67 \% \text { reduction in } \\
\text { overall casualty } \\
\text { rate, although } \\
\text { there was } \\
\text { markedly fewer } \\
\text { cranes and } \\
\text { bustards in the } \\
\text { area post-marking }\end{array}$ \\
\hline $\begin{array}{l}\text { Anderson 2002/ } \\
\text { Karoo, South } \\
\text { Africa/Various, } \\
\text { but mainly } \\
\text { Ludwig's Bustard } \\
\text { and Blue Crane }\end{array}$ & $400 \mathrm{kV}$ & $\begin{array}{l}2 \text { years / } \\
2 \text { sections } \\
\text { of } 5 \mathrm{~km}\end{array}$ & $\begin{array}{l}\text { PVC Bird Flight Diverter, } 90 \mathrm{~cm} \\
\text { long, attached to both earth-wires } \\
\text { every } 10 \mathrm{~m}\end{array}$ & $\begin{array}{l}\text { New line marked during } \\
\text { construction, compared } \\
\text { with nearby parallel, } \\
\text { unmarked line }\end{array}$ & - & $\begin{array}{l}42 \% \text { higher casualty } \\
\text { rate on new, } \\
\text { marked line, than } \\
\text { on unmarked line }\end{array}$ \\
\hline $\begin{array}{l}\text { Crowder 2000/ } \\
\text { Indiana, U.S.A/ } \\
\text { Various }\end{array}$ & $?$ & 2 years / ? & $\begin{array}{l}\text { BFDs and larger Swan Flight } \\
\text { Diverters }\end{array}$ & $\begin{array}{l}\text { Compare before and after } \\
\text { marking, and between the } \\
\text { two devices }\end{array}$ & - & $\begin{array}{l}\text { Both devices reduced } \\
\text { collision frequency, } \\
\text { BFD was most } \\
\text { effective, reducing } \\
\text { casualty rate by } 73 \%\end{array}$ \\
\hline $\begin{array}{l}\text { De la Zerda and } \\
\text { Roselli } 2003 / \\
\text { Colombia/ Night- } \\
\text { flying rallids, } \\
\text { herons and ducks }\end{array}$ & $500 \mathrm{kV}$ & $\begin{array}{l}3 \text { years / } 2 \\
\text { sections } \\
\text { of parallel } \\
\text { line }\end{array}$ & $\begin{array}{l}\text { Yellow PVC BFD spirals, } 80 \mathrm{~cm} \times \\
25 \mathrm{~cm} \text {, attached every 10 m, } \\
\text { staggered, on both earth wires }\end{array}$ & $\begin{array}{l}\text { One of lines marked, other } \\
\text { not, before and after } \\
\text { marking, and marked vs } \\
\text { unmarked comparison of } \\
\text { bird flight behaviour and } \\
\text { collision frequency }\end{array}$ & $\begin{array}{l}\text { Birds were able } \\
\text { to see the lines } \\
\text { and react to } \\
\text { them better } \\
\text { after marking, } \\
\text { but regardless } \\
\text { of whether or } \\
\text { not the lines } \\
\text { were marked }\end{array}$ & $\begin{array}{l}50 \% \text { reduction in } \\
\text { collision frequency } \\
\text { for marked vs } \\
\text { unmarked lines, } \\
\text { but collision rate } \\
\text { was highly } \\
\text { variable regardless } \\
\text { of line condition }\end{array}$ \\
\hline
\end{tabular}


Table 1. Continued.

\begin{tabular}{|c|c|c|c|c|c|c|}
\hline $\begin{array}{l}\text { Reference/ Geographic area/ } \\
\text { Affected taxa/ }\end{array}$ & Voltage of line/s & $\begin{array}{l}\text { Duration of } \\
\text { study / } \\
\text { length/s of } \\
\text { line }\end{array}$ & Size or variant of mitigating device & Experimental design & $\begin{array}{l}\text { Measured or } \\
\text { estimated effect } \\
\text { of mitigation on } \\
\text { behaviour? }\end{array}$ & $\begin{array}{l}\text { Measured or } \\
\text { estimated effect of } \\
\text { mitigation on } \\
\text { casualty rate? }\end{array}$ \\
\hline \multicolumn{7}{|c|}{ Dynamic 'swinging plate' or 'flappers' } \\
\hline $\begin{array}{l}\text { Brown and } \\
\text { Drewien 1995/ } \\
\text { Colorado, U.S.A./ } \\
\text { Cranes and } \\
\text { waterfowl }\end{array}$ & $\begin{array}{l}7.2 \text { and } \\
69-115 \mathrm{kV}\end{array}$ & $\begin{array}{l}3 \text { years / } 8 \\
\text { sections of } \\
1.2-2.4 \mathrm{~km} \text {, } \\
\text { total } \\
13.2 \mathrm{~km}\end{array}$ & $\begin{array}{l}\text { Yellow fibreglass plate, } 30.5 \mathrm{~cm} \times \\
30.5 \mathrm{~cm} \text {, with black stripe, } \\
\text { clamped to conductor on a hinge } \\
\text { to permit swinging, attached to } \\
\text { earth wires or centre conductor } \\
\text { every } 20-30 \mathrm{~m}\end{array}$ & $\begin{array}{l}\text { Half of each section marked, } \\
1 / 2 \text { left unmarked, all } \\
\text { checked daily, throughout } \\
3 \text { falls and } 3 \text { springs - bird } \\
\text { activity and response and } \\
\text { collision rates compared }\end{array}$ & $\begin{array}{l}\text { Birds reacted } \\
\text { earlier and flew } \\
\text { higher over } \\
\text { marked lines } \\
\text { than unmarked } \\
\text { lines }\end{array}$ & $\begin{array}{l}63 \% \text { reduction in } \\
\text { mortality rates } \\
\text { overall, but } \\
\text { considerable } \\
\text { seasonal variation. } \\
\text { Over } 30 \% \text { of } \\
\text { collisions in fall } \\
\text { occurred at night }\end{array}$ \\
\hline $\begin{array}{l}\text { Yee 2008/ California, } \\
\text { U.S.A./ Various, but } \\
\text { mainly Sandhill Cranes } \\
\text { and large waterfowl }\end{array}$ & $12 \mathrm{kV}$ & $\begin{array}{l}3 \text { years / } 5.6 \\
\mathrm{~km}\end{array}$ & $\begin{array}{l}\text { 'Firefly' bird 'flapper' }-15 \mathrm{~cm} \times 9 \mathrm{~cm} \\
\text { acrylic, with luminescent strip, } \\
\text { spinning swivel, with contrasting } \\
\text { colours on opposite sides, attached } \\
\text { to alternate conductors at } 5 \mathrm{~m} \\
\text { intervals }\end{array}$ & $\begin{array}{l}\text { Before marking surveys, } \\
\text { then } 5 \text { sections fitted } \\
\text { with 'flappers' } \\
\text { interspersed with } 5 \\
\text { sections left unmarked }\end{array}$ & $\begin{array}{l}\text { Bird flight } \\
\text { behaviour not } \\
\text { significantly } \\
\text { different } \\
\text { between } \\
\text { treatments }\end{array}$ & $\begin{array}{l}60 \% \text { reduction in } \\
\text { collision frequency } \\
\text { on marked lines, } \\
\text { collision frequency } \\
\text { also decreased on } \\
\text { spans neighbouring } \\
\text { marked spans }\end{array}$ \\
\hline $\begin{array}{l}\text { Anderson 2002/ Karoo, } \\
\text { South Africa/ Various, but } \\
\text { mainly Ludwig's Bustard } \\
\text { and Blue Crane }\end{array}$ & $132 \mathrm{kV}$ & $\begin{array}{l}2.5 \text { years / } \\
10 \mathrm{~km}\end{array}$ & $\begin{array}{l}\text { PVC Bird Flight Diverter, } 30 \mathrm{~cm} \\
\text { long, attached to both earth-wires } \\
\text { every 10 m. Two spans (o.7 km), } \\
\text { BFDs interspersed with 'flappers' } \\
\text { - polycarbon discs loosely } \\
\text { suspended from clamp }\end{array}$ & $\begin{array}{l}\text { Line previously fitted with } \\
\text { BFDs only - then collision } \\
\text { 'hot-spot' fitted with } \\
\text { flappers too: before and } \\
\text { after comparison }\end{array}$ & - & $\begin{array}{l}\text { A further } 52 \% \\
\text { reduction in } \\
\text { collisions with } \\
\text { addition of the } \\
\text { flappers and }>80 \% \\
\text { reduction from } \\
\text { unmarked to marked } \\
\text { with BFDs and } \\
\text { flappers. However, } \\
\text { crane and bustard } \\
\text { numbers much } \\
\text { lower in the area } \\
\text { generally because of } \\
\text { dry conditions }\end{array}$ \\
\hline
\end{tabular}


Table 1. Continued.

\begin{tabular}{|c|c|c|c|c|c|c|}
\hline $\begin{array}{l}\text { Reference/ Geographic area/ } \\
\text { Affected taxa/ }\end{array}$ & Voltage of line/s & $\begin{array}{l}\text { Duration of } \\
\text { study / } \\
\text { length/s of } \\
\text { line }\end{array}$ & Size or variant of mitigating device & Experimental design & $\begin{array}{l}\text { Measured or } \\
\text { estimated effect } \\
\text { of mitigation on } \\
\text { behaviour? }\end{array}$ & $\begin{array}{l}\text { Measured or } \\
\text { estimated effect of } \\
\text { mitigation on } \\
\text { casualty rate? }\end{array}$ \\
\hline $\begin{array}{l}\text { Anderson 2002/ Karoo, } \\
\text { South Africa/ Various, but } \\
\text { mainly Ludwig's Bustard } \\
\text { and Blue Crane }\end{array}$ & $400 \mathrm{kV}$ & $\begin{array}{l}2 \text { years / } \\
10 \mathrm{~km}\end{array}$ & $\begin{array}{l}\text { PVC Bird Flight Diverter, } 30 \mathrm{~cm} \\
\text { long, attached to both earth- } \\
\text { wires, staggered every 10 m or } 20 \\
\text { m. Polycarbon 'flappers' or discs } \\
\text { loosely suspended from clamp, } \\
\text { attached to both earth-wires, } \\
\text { staggered at 1o m or } 20 \mathrm{~m} \\
\text { intervals, with alternating black } \\
\text { and white discs }\end{array}$ & $\begin{array}{l}\text { Spans were alternately } \\
\text { marked: BFDs at } 10 \mathrm{~m} \\
\text { intervals, BFDs at } 20 \mathrm{~m} \\
\text { intervals, unmarked, BFs } \\
\text { at } 10 \mathrm{~m} \text { intervals, BFs at } \\
20 \mathrm{~m} \text { intervals, unmarked; } \\
\text { protocol repeated } 4 \times \text { over } \\
\text { 10 km section of line }\end{array}$ & - & $\begin{array}{l}\text { 'Flappers' about } 60 \% \\
\text { more effective } \\
\text { than BFDs, but } \\
\text { unmarked sections } \\
\text { also had lower } \\
\text { collisions than BFD } \\
\text { sections, and rate } \\
\text { did not decrease } \\
\text { with marker } \\
\text { interval as } \\
\text { expected. Also, } \\
\text { comparison of } \\
\text { overall collision } \\
\text { rate for the line } \\
\text { from clearing to } \\
\text { post-marking not } \\
\text { favourable }\end{array}$ \\
\hline
\end{tabular}

intervals, with alternating black

protocol repeated $4 \times$ over

protocol repeated $4 \times$ 
work done in this field is North American, with significant contributions from Scandinavia, southern Europe (Spain, Italy) and South Africa. Evidently, there are large areas of the world where the impact of power lines on birds remains largely unresearched.

The review papers covered the issue of bird collisions with power lines from a variety of thematic and geographic perspectives (Appendix 1 in Supplementary Materials) and yet present very similar assessments of the contributing factors, implicated species, possible biological consequences and available remedial actions. This is despite the fact that the time elapsed between the earliest and most recent cited review exceeds 15 years, during which a considerable amount of additional research was done. Such consistency comes partly from the use of common, seminal references, but also suggests that at least some of the fundamental biology of this phenomenon is well known and understood.

\section{Profiling collision-prone species}

There is good consensus on the typical characteristics of a collision-prone species, coupled with general recognition of a complex interplay between a wide range of key contributing factors (Bevanger 1994, Hunting 2002, Drewitt and Langston 2008). For any given bird, these factors are centred on the likelihood of flying horizontally at power line height (exposure to collision risk) and the ability to see the power lines ahead in time to avoid an imminent collision (inherent susceptibility to collision). Exposure to the risk of collision is largely a function of behaviour, and may be potentially high in very aerial species (because they spend so much time on the wing), but effectively reduced to negligible by their tendency to fly well above the ground (APLIC 1994, Bevanger 1994). In contrast, largely terrestrial species are much less exposed to collision risk because they spend so little time in flight, but their effective exposure is increased by doing most of their flying at around power line height. Exposure is further increased by a tendency to make regular, direct flights between resource points, and raised still further if localised resource areas encourage aggregation, and travel is mostly done in flocks (Brown 1992, APLIC 1994, Bevanger 1994, Hunting 2002). Hence, theoretically: exposure is greatest in flocking species which regularly commute at low altitudes, and lowest in solitary species which fly infrequently and at high altitudes. All species are potentially exposed, and most fall somewhere between these two extremes.

Susceptibility to collision is largely a function of morphology; ocular structure and acuity affect a bird's ability to see the power line in order to take evasive action (Bevanger 1994, Drewitt and Langston 2008), while size, weight and wing structure influence the time required to make the necessary adjustments (Brown 1992, Bevanger 1994, Rubolini et al. 2005). Obviously, reaction time is also affected by flight speed, which tends to be higher in species with relatively heavy bodies requiring more urgent forward momentum to remain airborne. To exacerbate this effect, a higher wing loading also confers reduced manoeuvrability (Bevanger 1994, Janss 2000). Hence, theoretically: large, heavy, relatively small-winged birds with poor vision are most susceptible to collision, while small, light, relatively large-winged birds with acute vision are least susceptible. All volant, terrestrial species are potentially susceptible, and most fall somewhere between these two extremes.

Again theoretically, net collision profile may be considered as the product of species-typical exposure and susceptibility characteristics. This proneness to collision is further influenced by aspects such as acquired knowledge of the whereabouts of power lines (greatest in experienced adults of resident species, and least in naïve juveniles of migratory species; Brown 1992, Crowder and Rhodes 2001) or distracting behaviours such as elaborate aerial displays, high-speed chasing, or pressure to deliver food to hungry nestlings (Henderson et al. 1996), may be significantly compounded by a tendency to fly at dusk, dawn or during the night (Bevanger 1994, Crowder and Rhodes 2001), and is potentially multiplied by the effects of local environmental conditions.

In more specific terms, birds which quite consistently appear in lists of implicated taxa are: waterbirds (which habitually congregate at wetlands and commute between them in flocks; particularly large and/or fast-flying species, such as large ducks, geese and swans, pelicans, 
flamingos, large herons and waders, have highest susceptibility), gamebirds and rails (which have limited exposure but are highly susceptible; Bevanger 1998), and cranes and bustards (both of which, as large, heavy-bodied, flocking, low-level commuters are highly exposed and susceptible).

Importantly, smaller species which are theoretically prone to collision - pigeons, various passerines, solitary, high-speed predators such as falcons - may be under-represented in these lists, perhaps simply because they are less likely to be found in line surveys (Hunting 2002, Drewitt and Langston 2008).

The species apparently most prone to colliding with power lines in South Africa (Eskom/EWT Strategic Partnership 2008, Figure 1), fall conveniently into the various collision-prone groups identified in global reviews, being predominantly large terrestrial or wetland species (e.g. Blue Crane Anthropoides paradiseus $>700$ recorded collisions, Ludwig's Bustard Neotis ludwigii > 200 records, White Stork Ciconia ciconia nearly 200 records, Grey Crowned Crane Balearica regulorum $>100$ records). However, these figures are not the product of structured power line surveys, but rather aggregated totals of incidental casualty records accumulated over a 12-year period (Eskom/EWT Strategic Partnership 2008). As such, they cannot be regarded as representing more than an initial indication of the nature and scale of the problem in this region.

Environmental conditions may strongly affect both exposure to collision risk (by modulating bird behaviour), and susceptibility to collision (by enhancing or impairing a bird's physical capacity to avoid hitting the lines). For example, a highly susceptible species flying over heavily forested habitat in which average tree height equals or exceeds power pylon height, has minimal exposure and is very unlikely to collide with power lines because it is forced by environmental conditions to fly above them. Similarly, a light, agile species with low susceptibility under normal conditions may be highly susceptible to collision when flying in misty, windy conditions because its vision and flying abilities are impaired.

Particularly important components of the local environment are topography, vegetation and weather (Brown 1992, APLIC 1994, Bevanger 1994, Hunting 2002, Drewitt and Langston 2008). Topographic relief patterns affect the alignment of avian flight paths, particularly where they fly close to the ground, channelling them into valleys, over passes, along ridges and into depressions as they follow energetically expedient ways to travel cross-country. Such channelling can be critical in determining risk exposure for commuting birds in a landscape traversed by multiple power lines (APLIC 1994, Bevanger 1994, Hunting 2002). As much as tall vegetation may raise the prevailing flight altitude of flying birds, short, open vegetation encourages lower altitude flying (APLIC 1994), and is also the habitat structure typically favoured by large, terrestrial species with high collision susceptibility. Mist, fog, low cloud and any form of precipitation can obviously affect visibility, and although most birds reduce their collision exposure by flying less under such circumstances, any that do take to the air are much more susceptible to power line collision (Brown 1992, Drewitt and Langston 2008). Strong winds, especially tail- or cross-winds, blunt the fine motor control of flying birds and consequently raise their susceptibility to collision (Bevanger 1994, Crowder and Rhodes 2001).

There have been no studies which specifically examine the influence of environmental parameters on collision risk in South African birds. However, it may be pertinent to note that much of the South African countryside is covered by open grassland or semi-arid Karoo which harbours globally significant bustard and crane fauna (Anderson 2000a,b, 2002, Allan 2005a,b), so the issue of power line collisions is likely to be both prevalent and impactful in this region.

\section{Casualty rates and demographic effects}

Most of the published studies on power line collision rates have focused on short sections of power line (often $<15 \mathrm{~km}$ ) at particular collision 'hot-spots' (often in close proximity to significant wetlands), and have run over multiple years or seasons (Appendix 2 in Supplementary Materials). Collision rates have been measured in various units, in some cases relative to the measured abundance and risk exposure of the species observed in the area (Faanes 1987, 
Henderson et al. 1996). For comparative purposes, these have been recalculated where possible to a simple, common unit - casualties $/ \mathrm{km} /$ year. Some studies have corrected for measured or estimated sources of bias, allowing for the effects of removal of remains by scavengers, detectability of carcasses in different habitats, and the disappearance of birds injured but not immediately killed in collisions which has effectively doubled or even tripled their final estimate of collision rates (Faanes 1987, Janss and Ferrer 2000, Bevanger and Brøseth 2004).

Collision rate estimates vary from about 0.1 to nearly 80 casualties $/ \mathrm{km} /$ year, probably depending largely on the number of species included in the final figure, and the extent to which a study was focused on a high-collision zone (e.g. Faanes 1987), as opposed to attempting to measure collision risk for local populations of $1-2$ species over a much broader area (typically the case in studies of non-wetland situations). The majority of authors refer to the casualty rates measured as sustainable by the bird populations affected, again particularly because the losses sustained are highly localised and often accrue to fairly common and widespread species (e.g. Rusz et al. 1986, Faanes 1987). However, where an effort has been made to extrapolate from focal studies to accumulated, widespread effects, even in quite common species (Bevanger 1995, Bevanger and Brøseth 2004), or else research has concentrated on the possible impact of additional, artificial mortality on rare or threatened species (Brown et al. 1987, Crivelli et al. 1987, Bevanger 1998, Janss and Ferrer 2000, Mañosa and Real 2001, Stehn and Wassenich in press), then the long-term implications of power line collisions for bird conservation appear more severe.

Despite (i) the relatively large numbers of incidental collision records compiled for South African power lines (van Rooyen and Ledger 1999, van Rooyen 2000, 2001, McCann and van Rooyen 2002, Eskom/EWT Strategic Partnership 2008), (ii) the fact that eight of the top 10 species most frequently reported as collision casualties in South Africa are red-listed (Barnes 2000, van Rooyen 2001), and (iii) a wealth of anecdotal information on high collision casualty counts from many parts of the country, there is only one South African study which details bird:power line collision rates per unit length of line, collected over a protracted period, and with repeated sampling (Anderson 2002). Even without correcting for scavenging, habitat and crippling biases, this study estimated collision rates of $1-3$ casualties $/ \mathrm{km} /$ year for Blue Crane and Ludwig's Bustard in a representative area of the Eastern Karoo. If these levels of mortality are sustained over a broader area, they may well be having a significant negative effect on the populations of both these threatened species (Anderson 2002, Jenkins and Smallie 2009).

Ludwig's Bustard is of particular concern given what we know about its biology: it is a large, heavy-bodied species which inhabits open, arid country, and lives and moves in loose flocks. While it is relatively cumbersome in the air, it is highly seasonally nomadic, flying long distances into areas of the Karoo after recent rainfall events, and also commuting every day, at first and last light, between roost sites on hilltops and feeding areas on the plains (Allan 2005a). Thus, Ludwig's Bustard is extreme in terms of both its exposure and its susceptibility to collision with power lines (Jenkins and Smallie 2009).

\section{Mitigation options: planning ahead}

Previously suggested means for limiting bird:power line collisions range from proactive to reactive, with the former approaches dependent on a sound foundation of distributional and behavioural data, and the latter requiring critical understanding of avian perception. In both cases it is imperative that perception is assessed in terms of empirical data from the field, theory is put to practical testing, and that the efficacy of implemented mitigation measures is properly and objectively measured.

The surest ways to prevent birds from colliding with a proposed power line are either not to build it, to bury it underground, or to route it well away from areas known or considered likely to support collision-prone species (Hunting 2002, Drewitt and Langston 2008). Hence, all new power lines should be subjected to a rigorous environmental impact assessment, bird collision risk 
should be an important component of such an assessment (with adequate time and effort put into determining which birds are likely to be impacted and to what extent), and legislative frameworks must enable authorities to disallow, bury or re-route new lines in terms of their potential impact on local avifauna. Given the complexity of the bird:power line dynamic, there are few hard and consistent rules which can be applied to power line installation and routing regardless of species complement and prevailing conditions. Routing lines over or close to water bodies is clearly problematic and certain topographic features - valley heads, ridge tops - are probably also high risk options (APLIC 1994, Hunting 2002).

Designing and building relatively 'bird-friendly' power lines, which incorporate bird collision risk in both placement and in technical configuration is another proactive means of mitigating collision risk. Again, specifics are likely to be case-dependent, but there is general agreement that (i) lines should be kept as low as possible, (ii) span lengths should be kept as short as possible, (iii) cabling used should be as thick as possible, (iv) vertically separated arrays of lines should be avoided as much as possible, (v) lines of similar height and structure with common sources and destinations should run in close parallel in effectively a common servitude, and (vi) lines with very different heights and configurations should be kept well apart (APLIC 1994, Bevanger 1994, Hunting 2002).

Once power lines have been built, it is still possible to manage bird collision proactively by using the available information on previous collisions, avifauna, topography, vegetation and land use to anticipate where as yet undetected high risk sections of line might be located (e.g. Heck 2007).

\section{Experimental evidence}

Either in a proactive or reactive context, modifying power lines to make them less dangerous and/ or more conspicuous and visible to on-flying birds is the only other commonly used approach to collision mitigation globally, and is by far the most widely applied (APLIC 1994, Hunting 2002, Crowder and Rhodes 2001, Drewitt and Langston 2008). While there is a remarkable dearth of good-quality empirical and experimental evidence to vouch for the efficacy of this method, the evidence that has been gathered to date, in studies conducted in the U.S.A., Norway, Spain, South America and South Africa, points to generally positive results (Table I).

Because birds usually collide with the highest and/or thinnest components of a power line array, and these are usually the earth- or ground-wires, simple removal of these wires is one way to reduce the frequency of collisions (Brown et al. 1987, Bevanger and Brøseth 2001). This has been shown to be effective in protecting birds as varied in size and biology as cranes and ptarmigan (Table I). However, barring the development of economical alternatives for lightning conduction on high-voltage power line installations, earth-wire removal is unlikely to be accepted by power utilities as a viable mitigation option for general use, even though in many cases earth wires may not be an absolute requirement for safe and reliable power delivery.

A study of the use of raptor silhouettes placed on pylons as deterrents to reduce bird traffic over lines and thereby reduce collisions (Janss et al. 1999), was far from exhaustive, but seemed to demonstrate conclusively that this is an entirely ineffective practice.

Marking lines to make them more visible is the remaining option, and a wide range of possible markers have been suggested and developed. Only a fraction of these have been properly fieldtested, but nearly all of the devices tested have yielded at least moderate reductions in collision frequency. In fact, on the evidence available (and barring some notable exceptions), any sufficiently large form of marker (which thickens the appearance of the line at that point by at least $20 \mathrm{~cm}$, over a length of at least $10-20 \mathrm{~cm}$ ), placed with sufficient regularity (at least every 5$10 \mathrm{~m}$ ) on either the earth wires (preferably) or the conductors, is likely to lower general collision rates by $50-80 \%$. Unfortunately, there is no legitimate way to compare the results of these studies because of the wide variety of species and conditions involved. In studies which compared two forms of marker under the same conditions (Janss and Ferrer 1998, Brown and Drewien 1995, 
Crowder 2000, Anderson 2002), only thin plastic strips used on a distribution line in Spain (Janss and Ferrer 1998) proved obviously inferior to the alternatives, otherwise the effective differences between neoprene bands and large bird flight diverters (BFDs) (Janss and Ferrer 1998), vibration dampers and large, swinging fibreglass plates (Brown and Drewien 1995), and medium and large ('Swan') BFDs (Crowder 2000) was negligible. Several 'advances' proposed in the last decade - the emphasis on appropriate (yellow or yellow-green) or alternating (dark and light) colouration to maximize effect within the avian visual spectrum (Crowder and Rhodes 2001), and an insistence on dynamic 'flapper' devices as substitutes for static aviation spheres, vibration dampers or BFDs - may well have some merit, but are not currently supported by any solid field data. Notably, while a number of authors have pointed to the importance of nocturnal collisions in contributing to total casualty counts (e.g. Brown and Drewien 1995, Hunting 2002), little, if any, documented progress has been made in the development of an effective illuminating marker to address this aspect of the problem.

Only one South African study has included experimentation with various types and combinations of power line markers (Anderson 2002) The most significant findings were (i) that markers of any description may not be effective in reducing Ludwig's Bustard fatalities (note: a similar finding was made in Spain for Great Bustard Otis tarda collisions; Janss and Ferrer 1998), (ii) that huge variation in the abundance of bustards and cranes in the semi-arid Karoo made comparing the efficacies of marking devices over time almost impossible and (iii) a combination of bird 'flappers' and BFDs lowered collision rate on an experimental section of line by over $80 \%$. In the most ambitious part of this project, the performances of dynamic 'flappers' and static BFDs were compared. Unfortunately, this experiment was probably too complex in design, with too many marker permutations crammed into too short a section of line, and the results were inconclusive (Anderson 2002).

\section{Conclusion}

Avian collisions with power lines occur worldwide, and must be an escalating source of unnatural mortality for birds generally as power grids grow rapidly across the globe. Collisions generally have no functional effect on power delivery for utilities, and may not even be of demographic consequence to many of the implicated bird taxa. However, in some instances they constitute a significant source of unnatural mortality for already severely threatened species, and in all cases they add to a growing list of sources of anthropogenic mortality - including a variety of other forms of collision (Erickson et al. 2005) - which collectively must be putting the world's birds under increasing, and perhaps ultimately unsustainable, pressure. While we have made some progress in the development of effective mitigation for this phenomenon, research efforts to date have fallen short of delivering an all-purpose and consistently effective line-marking device, perhaps partly because conditions and species-specific requirements are so variable, both in space and time, but also because the spatial and temporal scales, and experimental rigour and standards, have not been sufficient to achieve this objective.

In general, very few published or reported studies have measured comparable collision rates, established the demographic impact of power line collisions on the bird populations involved, or assessed the efficacy and value of the available methods for mitigating collision risk.

This paucity of quantitative research applies particularly to the South African situation, despite the fact that a considerable amount of applied management of power line impacts has been done in this region. Given the uniquely collaborative nature of the Eskom/EWT Strategic Partnership, and the possibly dire impacts of power line collisions on at least one of South Africa's most threatened birds - Ludwig's Bustard - we suggest that a comprehensive research programme to address this deficiency is appropriate and timely. Such a programme would aim to raise our understanding of the scale and consequences of power line collisions on South African birds well above its present level, provide conclusive experimental evidence for or against the various collision mitigation devices currently in circulation, examine possible alternatives to line marking 
and, most importantly, reduce collision casualty rates in South African bustards, cranes and waterbirds.

\section{Acknowledgements}

This study was funded by Eskom Sustainability and Innovation Division. Sincere thanks to Michael D. Michael for his help and encouragement in developing the WEIG research programme, and for the part he continues to play in cultivating a productive and rewarding relationship between WEIG and Eskom.

\section{References}

ABS Energy Research (2008) The T and D Report, Edition 7. London: ABS Energy Research.

Allan, D. G. (2005a) Ludwig's Bustard. Pp. 293-294 in P. A. R. Hockey, W. R. J. Dean and P. G. Ryan, eds. Roberts birds of southern Africa, VII. Cape Town: John Voelcker Bird Book Fund.

Allan, D. G. (2005b) Blue Crane. Pp. 309-311 in P. A. R. Hockey, W. R. J. Dean and P. G. Ryan, eds. Roberts birds of southern Africa, VII. Cape Town: John Voelcker Bird Book Fund.

Alonso, J. C., Alonso, J. A. and MunozPulido, R. (1994) Mitigation of bird collisions with transmission lines through groundwire marking. Biol. Conserv. 67: 129-134.

Anderson, M. D. (2000a) Blue Crane. Pp. 9294 in K. N. Barnes, ed. The Eskom Red Data Book of birds of South Africa, Lesotho and Swaziland. Johannesburg: BirdLife South Africa.

Anderson, M. D. (200ob) Ludwig's Bustard. Pp. 105-107 in K. N. Barnes, ed. The Eskom Red Data book of Birds of South Africa, Lesotho and Swaziland. Johannesburg: BirdLife South Africa.

Anderson, M. D. (2002) Karoo Large terrestrial bird powerline project, report No. I. Johannesburg: Eskom (Unpublished report).

APLIC (Avian Power Line Interaction Committee) (1994) Mitigating bird collisions with power lines: the state of the art in 1994. Washington DC: Edison Electric Institute.

Barnes, K. N., ed. (200o) The Eskom Red Data Book of birds of South Africa, Lesotho and
Swaziland. Johannesburg: BirdLife South Africa.

Bevanger, K. (1994) Bird interactions with utility structures: collision and electrocution, causes and mitigating measures. Ibis 136: 412-425.

Bevanger, K. (1995) Estimates and population consequences of Tetraonid mortality caused by collisions with high tension power lines in Norway. J. Appl. Ecol. 32: 745-753.

Bevanger, K. (1998) Biological and conservation aspects of bird mortality caused by electric power lines. Biol. Conserv. 86: $67-76$.

Bevanger, K. and Brøseth, H. (2001) Bird collisions with power lines - an experiment with ptarmigan (Lagopus spp.). Biol. Conserv. 99: 341-346.

Bevanger, K. and Brøseth, H. (2004) Impact of power lines on bird mortality in a subalpine area. Anim. Biodiv. Conserv. 27: 67-77.

Brown, W. M. (1992) Avian collisions with utility structures: biological perspectives. Pp. 12-1-12-13 in Proceedings of the international workshop on avian interactions with utility structures. Miami, USA: APLIC/EPRI.

Brown, W. M. and Drewien, R. C. (1995) Evaluation of two power line markers to reduce crane and waterfowl collision mortality. Wildl. Soc. Bull. 23: 217-227.

Brown, W. M., Drewien, R. C. and Bizeau, E. G. (1987) Mortality of cranes and waterfowl from powerline collisions in the San Luis Valley, Colorado. Pp. 128-136 in J. C. Lewis, ed. Proceedings of the crane workshop, 1985. Grand Island, Nebraska: Platte River Whooping Crane Maintenance Trust. 
Crivelli, A. J., Jerrentrup, H. and Mitchev, T. (1987) Electric power lines: a cause of mortality in Pelecanus crispus Bruch, a world endangered bird species, in Porto-Lago, Greece. Colonial Waterbirds 11: 301-305.

Crowder, M. R. (2000) Assessment of devices designed to lower the incidence of avian power line strikes. Unpublished MSc Thesis. Purdue University, West Lafayette.

Crowder, M. R. and Rhodes, O. E. (2001) Avian collisions with power lines: A review. Pp. 139-167 in Proceedings of a workshop on avian interactions with utility and communications structures. Charleston: EPRI (EPRI Technical Report No. 1006907).

De la Zerda, S. and Roselli, L. (2003) Mitigación de collision de aves contra líneas de transmission eléctrica con marcaje del cable de guarda. Ornithología Colombiana r: 42-62.

Drewitt, A. L. and Langston, R. H. W. (2008) Collision effects of wind-power generators and other obstacles on birds. Ann. New York Acad. Sci. 1134: 233-266.

Erickson, W. P., Johnson, G. D. and Young, Jr., D. P. (2005) A summary and comparison of bird mortality from anthropogenic causes with an emphasis on collisions. Washington DC: USDA Forest Service General Technical Report PSW-GTR-191.

Eskom/EWT Strategic Partnership. (2008) Central incident register. Held and curated by the Wildlife and Energy Interaction Group, Johannesburg: Endangered Wildlife Trust.

Faanes, C. A. (1987) Bird behaviour and mortality in relation to power lines in prairie habitats. U.S. Fish and Wildlife Service Technical Report 7: 1-24.

Heck, N. (2007) A landscape-scale model to predict the risk of bird collisions with electric power transmission lines in Alberta. Unpublished MSc thesis. University of Calgary, Calgary.

Henderson, I. G., Langston, R. H. W. and Clark, N. A. (1996) The response of Common Terns Sterna hirundo to power lines: an assessment of risk in relation to breeding commitment, age and wind speed. Biol. Conserv. 77: 185-192.
Hunting, K. (2002) A roadmap for PIER research on avian collisions with power lines in California. Sacramento, CA: Prepared for the California Energy Commission, Public Interest Energy Research Program. Report No. P500-02-071F.

IEEE Task Force (2004) Preventive measures to reduce bird-related power outages - Part I: Electrocution and collision. IEEE Transactions on Power Delivery 19: 1843-1847.

Janss, G. F. E. (2000) Avian mortality from power lines: a morphologic approach of a species-specific mortality. Biol. Conserv. 95: 353-359.

Janss, G. F. E. and Ferrer, M. (1998) Rate of bird collision with power lines: effects of conductor-marking and static wiremarking. J. Field Ornithol. 69: 8-17.

Janss, G. F. E. and Ferrer, M. (200o) Common crane and great bustard collision with power lines: collision rate and risk exposure. Wildl. Soc. Bull. 28: 675-68o.

Janss, G. F. E., Lazo, A. and Ferrer, M. (1999) Use of raptor models to reduce avian collisions with powerlines. J. Raptor Res. 33: 154-159.

Jenkins, A. and Smallie, J. (2009). Terminal velocity: end of the line for Ludwig's Bustard? Africa - Birds and Birding 14: 34-39.

Jenkins, A., Smallie, J., Diamond, M., Allan, D., Anderson, M., Boshoff, A. and Botha, A. (2008) Interactions between wildlife and the energy and communications industries in southern Africa: identifying future research priorities. Unpublished report. Johannesburg: Endangered Wildlife Trust.

Kelly, A. and Kelly, S. (2005) Are Mute Swans with elevated blood lead levels more likely to collide with overhead lines? Waterbirds 28: 331-334.

Lehman, R. N., Kennedy, P. L. and Savidge, J. A. (2007) The state of the art in raptor electrocution research: a global review. Biol. Conserv. 136: 159-174.

Mañosa, S. and Real, J. (2001) Potential negative effects of collisions with transmission lines on a Bonelli's Eagle population. J. Raptor Res. 35: 247-252.

McCann, K. and van Rooyen, C. (2002) Wildlife/power interactions. Pp. $23-29$ in Proceedings of the $14^{\text {th }}$ South African 
Crane Working Group Workshop. Johannesburg: Endangered Wildlife Trust.

Morkill, A. E. and Anderson, S. H. (1991) Effectiveness of marking powerlines to reduce Sandhill Crane collisions. Wildl. Soc. Bull. 19: 442-449.

Pullin, A. S. and Stewart, G. B. (2006) Guidelines for systematic review in conservation and environmental management. Conserv. Biol. 20: 1647-1656.

Rubolini, D., Gustin, M., Bogliani, G. and Garavaglia, R. (2005) Birds and powerlines in Italy: an assessment. Bird Conserv. Internatn. 15: 131-145.

Rusz, P. J., Prince, H. H. and Rusz, R. D. (1986) Bird collisions with transmission lines near a power plant cooling pond. Wildl. Soc. Bull. 14: 441-444.

Savereno, A. J., Savereno, L. A., Boettcher, R. and Haig, S. M. (1996) Avian behaviour and mortality at power lines in coastal South Carolina. Wildl. Soc. Bull. 24: 636-648.

Stehn, T. and Wassenich, T. (In press) Whooping Crane collisions with power lines: an issue paper. Proceedings of the $10^{\text {th }}$ North American Crane Workshop.

Sundar, K. S. G. and Choudhury, B. C. (2005) Mortality of sarus cranes (Grus antigone) due to electricity wires in Uttar Pradesh, India. Environ. Conserv. 32: 260-269.

van Rooyen, C. S. (2000) Raptor mortality on powerlines in South Africa. Pp. 739-749 in R. D. Chancellor and B.-U. Meyburg, eds. Raptors at risk. Berlin: WWGBP/Hancock House.

van Rooyen, C. S. (2001) An overview of the Eskom-EWT Strategic Partnership in South Africa. Pp. 13-28 in Proceedings of a workshop on avian interactions with utility and communications structures. Charleston: EPRI. (EPRI Technical Report No. 1006907).

van Rooyen, C. S. and Ledger, J. A. (1999) Birds and utility structures: developments in South Africa. Pp. 205-230 in M. Ferrer and G. F. E. Janss, eds. Birds and power lines: collision, electrocution and breeding. Madrid: Quercus.

Yee, M. L. (2008) Testing the effectiveness of an avian flight diverter for reducing avian collisions with distribution power lines in the Sacramento Valley, California. Sacramento, CA: California Energy Commission, PIER Energy-Related Environmental Research Program. CEC-5002007-122.

\section{ANDREW R. JENKINS ${ }^{t *}$, JON J. SMALLIE, MEGAN DIAMOND \\ Wildlife and Energy Interaction Group, Endangered Wildlife Trust, Private Bag X11, Parkview 2122, Johannesburg, South Africa.}

\footnotetext{
*Author for correspondence; e-mail: Andrew.Jenkins@uct.ac.za

${ }^{\dagger}$ Present address: Percy FitzPatrick Institute of African Ornithology, University of Cape Town, Rondebosch 7701, South Africa.
}

Received 27 January 2009; revision accepted 7 September 2009; Published online 19 March 2010 